Original Article

Artigo Original

Rafaella Cristina Oliveira ${ }^{1}$

Juliana Nunes Santos ${ }^{2}$

Alessandra Terra Vasconcelos Rabelo ${ }^{1}$

Max de Castro Magalhães ${ }^{3}$

Keywords

Noise

Noise Effects

Hearing Loss

Tinnitus

Sound Contamination

Descritores

Ruído

Efeitos do Ruído

Perda Auditiva

Zumbido

Poluição Sonora

Correspondence address:

Rafaella Cristina Oliveira

Rua Benjamim Brandão, 60, Paraíso,

Belo Horizonte (MG), Brasil,

CEP: 30270-160.

E-mail: rafaellacris_bh@hotmail.com

Received: 08/27/2014

\section{The impact of noise exposure on workers \\ in Mobile Support Units}

\author{
O impacto do ruído em trabalhadores \\ de Unidades de Suporte Móveis
}

\begin{abstract}
Purpose: To investigate the presence of auditory and nonauditory symptoms in professionals working in ambulances. Methods: This was a descriptive cross-sectional study with a convenience sample. Thirty-six professionals working in mobile support units, including drivers and nursing technicians from two private urgency and emergency services in the city of Belo Horizonte, Minas Gerais, Brazil, participated in the study. A questionnaire containing 17 multiple-choice questions was applied to the participants with questions regarding life history and occupation, family history of hearing loss, use of medications, and presence of auditory and nonauditory symptoms, among others. The professionals answered the questionnaire individually, in their workplaces, and received help from the researcher to understand the content of questions, if needed. Data were statistically analyzed using the Statistical Package for the Social Sciences (SPSS) software, version 16.0. Results: The most reported auditory symptoms were tinnitus, intolerance to intense sounds, and ear plenitude. The most reported nonauditory symptoms were irritability, headache, talking difficulties in noisy environments, and sleep alterations. A difference $(\mathrm{p} \leq 0.05)$ was observed when the relation between self-perception of drivers and nursing technicians on hearing acuity, presence of tinnitus, irritability, and communication difficulty was analyzed. Conclusion: Auditory and nonauditory symptoms are frequent in workers from mobile support units. An association between the worker's symptoms and the performed function was also observed. The results indicate a need of developing preventive actions regarding general health, which are aimed at the preservation of hearing health and quality of life of these professionals.
\end{abstract}

\section{RESUMO}

Objetivo: Investigar a presença de sintomas auditivos e não auditivos em profissionais que atuam em ambulâncias. Métodos: Estudo transversal descritivo com amostra de conveniência. Participaram 36 profissionais que atuam em unidades de suporte móveis, incluindo motoristas e técnicos de enfermagem de dois serviços particulares de urgência e emergência na cidade de Belo Horizonte, Minas Gerais. Foi aplicado um questionário contendo 17 questões de múltipla escolha sobre a história de vida e ocupação, antecedente familiar de perda auditiva, uso de medicamentos, presença de sintomas auditivos e não auditivos, entre outras investigações. Os profissionais responderam o questionário individualmente, no seu ambiente de trabalho, e, na existência de dificuldade de compreensão das questões, a pesquisadora explicou o conteúdo da questão. Os dados foram analisados estatisticamente utilizando-se o software Statistical Package for the Social Sciences (SPSS) 16.0. Resultados: Os sintomas auditivos mais relatados pelos profissionais foram zumbido, intolerância a sons intensos e plenitude auricular. Os sintomas não auditivos mais frequentes foram irritabilidade, dor de cabeça, dificuldade de conversar em ambiente ruidoso e alteração do sono. Foi observada diferença $(\mathrm{p} \leq 0,05)$ ao se analisar a relação entre autopercepção de motoristas e técnicos de enfermagem sobre acuidade auditiva, presença de zumbido, irritabilidade e dificuldade de comunicação. Conclusão: Sintomas auditivos e não auditivos são frequentes em trabalhadores de unidades de suporte móveis. Pôde-se observar associação entre sintomas e função desempenhada pelo trabalhador. Dessa forma, verifica-se a necessidade do desenvolvimento de ações preventivas voltadas à saúde geral, visando à preservação da saúde auditiva e qualidade de vida desses profissionais.

Study carried out at Universidade Federal de Minas Gerais - UFMG - Belo Horizonte (MG), Brazil.

(1) Graduate Program in Structure Engineering, Universidade Federal de Minas Gerais - UFMG - Belo Horizonte (MG), Brazil.

(2) Speech Language Pathology and Audiology Department, Universidade Federal de Minas Gerais - UFMG Belo Horizonte (MG), Brazil.

(3) Structure Engineering Department, Universidade Federal de Minas Gerais - UFMG - Belo Horizonte (MG), Brazil.

Conflict of interests: nothing to declare. 


\section{INTRODUCTION}

One can find many stressor agents that will interfere in the professionals' health and performance in the workplace. These agents may be physical, chemical, or organizational. Among the physical agents, we can highlight noise, heat, vibrations, pressures, and radiations, whereas the chemicals include smoking, dust, gases, and vapor. The organizational stressors are associated with work organization, such as shifts, rhythm, and ergonomics. All agents change the body functioning and sleep, increase sensitivity to environmental stressor agents, and consequently increase the risk of work accidents. When combined, these stressor agents may have a series of effects on health, influencing the attention skills and decreasing performance in both intellectual and physical activities ${ }^{(1,2)}$.

Noise stands out among the occupational risk agents. It is known that workers exposed to noise complain of communication difficulties, including alteration in the detection, discrimination, and location of the sound source, as well as in speech intelligibility, among many other symptoms, such as concentration and attention difficulty, memory, nervousness, and excessive fatigue ${ }^{(3)}$. In addition, studies show that exposure to noise affects the sympathetic nervous and endocrine systems, thus resulting in physiological responses such as increase of heart rate, increase of blood pressure, and vasoconstriction ${ }^{(4)}$.

Traffic noise is an important source of environmental pollution in developed and developing countries. Professional drivers are more susceptible to high levels of long noises. The main objective to protect drivers from auditory effects of the occupational noise is preserving hearing for speech discrimination ${ }^{(5)}$. A study carried out in India identified noise levels in bus booths of 89 to $106 \mathrm{~dB}(\mathrm{~A})$, and observed that $89 \%$ bus drivers had altered audiograms, that is, hearing impairment. Researches about noise in several kinds of transportation in New Delhi showed that, among the many kinds of transportation, noise levels are higher in rickshaws (81-96 dB(A)), followed by trucks (83-90 dB(A)), and buses (77-92 dB(A)). Noise levels in cars were considerably lower $(72-80 \mathrm{~dB}(\mathrm{~A}))$ when compared to other kinds of transportation. In ambulances, the noise level found after using a sound signal (siren) varied from 116 to $118 \mathrm{~dB}(\mathrm{~A})$. Specialized literature shows that $65 \mathrm{~dB}(\mathrm{~A})$ is considered an acceptable noise level, however levels above $80 \mathrm{~dB}(\mathrm{~A})$ are a serious reason of concern ${ }^{(6)}$.

The Regulatory Standard number 15 (NR-15), Administrative Rule number 3,214/1978, defines the limits of exposure to continuous or intermittent noise and to impact noises, effective in Brazil. The maximum exposure allowed for a noise of $85 \mathrm{~dB}(\mathrm{~A})$ is 8 hours a day ${ }^{(7)}$.

Presence of a continuous noise above $85 \mathrm{~dB}(\mathrm{~A})$ in a workplace may injure workers' auditory system and cause hearing loss. Hearing loss induced by noise (HLIN) is the alteration of hearing thresholds, of sensorineural kind, due to systematic occupational exposure to high sound pressure levels. At first, the harm damages hearing in higher frequencies around 4,000 Hz and then it progressively affects lower frequencies. Subjects only notice this irrecoverable loss when their talking frequencies are affected, which makes their relation with other people harder. In addition, if no decrease or elimination of noise exposure is done, there will be a worsening of the auditory $\operatorname{loss}^{(8)}$.

Furthermore, noise exposure can cause tinnitus, headache, auricular plenitude, dizziness, and gastric, visual, sleep, and mood disorders ${ }^{(9)}$. These disorders related to continuous noise exposure will depend on frequency, intensity, duration, and rhythm of the noise, as well as exposure time and individual susceptibility ${ }^{(10)}$.

Considering the harms that noise causes to people exposed to it, taking measures to decrease the sound pressure levels in workplaces is necessary. The most frequent way of solving this problem is by providing workers some auricular protectors ${ }^{(11)}$. Therefore, training educational actions focused on the importance of auditory protection are needed and efficient ${ }^{(12)}$.

The occupational exposure to noise due to vehicle traffic, sound alarms, and siren use is a worrisome factor for the auditory health of workers that work in mobile units, more specifically the ambulances.

Many investigations are available in literature about the levels of noise and auditory findings in bus and truck drivers ${ }^{(11,13)}$; however, only few studies analyze these findings in ambulance workers.

A study carried out in a city of Fars province, Iran, analyzed hearing skills of 500 truck drivers through pure tonal audiometry. Results indicated that the hearing harms in drivers were early in the frequencies of 4,000 and 8,000 Hz. Besides, they showed that work conditions of truck drivers could have a bilateral and symmetrical harming effect and could reach all frequencies, especially $4,000 \mathrm{~Hz}^{(11)}$.

Because hearing has an essential importance for human communication, and HLIN may result in damages to the subject, including a significant interference in his/her professional performance, knowledge of auditory and nonauditory symptoms of workers from mobile support units will contribute for the creation of measures to control and/or minimize the effects of noise in this workplace.

On the basis of what was previously mentioned, it is believed that workers from mobile support units are exposed to noise levels above those established in the Brazilian standards. This has a negative impact on auditory health and on the workers' quality of life.

Thus, the study aimed at investigating the presence of auditory and nonauditory symptoms in professionals that work inside ambulances and their association with the performed occupation.

\section{METHODS}

This is a cross-sectional descriptive study of two urgency and emergency private services and their workers in the city of Belo Horizonte, Minas Gerais, Brazil. The Speech Language 
Pathology and Audiology and Structure Engineering Departments and the University Research Ethics Committee analyzed and approved the research, under number 12711013.5.0000.5149.

Thirty-seven professionals from mobile support units took part in the study, including drivers and nursing technicians from two companies in the area of urgency and emergency in the city of Belo Horizonte. One professional was not included for reporting ear surgery. The sample comprised 36 participants, $5(13.9 \%)$ women and $31(86.1 \%)$ men, with ages varying from 27 to 69 years.

Professionals who worked in these mobile support units for at least a year and did not have any other complementary work activity in environments with noise above $85 \mathrm{~dB}(\mathrm{~A})$ at the time of research were included. Professionals who reported undergoing an ear surgical procedure, or who did not agree in taking part of the research, or were in vacation or sick leave during data collection were excluded.

First, we made contact with company delegates to present the research, its objectives, and repercussions. The directors agreed with the study and signed the consent letter. Then, explanations and orientations about the research procedures were provided to the participants. They received written information (informed consent) regarding the objective, importance, disclosure, risks, and benefits of the research, about volunteer participation, and the right to give up participation at any time of the study without losing any benefits.

The investigation was carried out applying a questionnaire including identification data and information about life history and occupation, family history of hearing loss, use of drugs, and presence of auditory and nonauditory symptoms, among other investigations of possible causes of hearing loss. The investigator adapted this questionnaire based on the standard of Fernandes and Morata ${ }^{(14)}$, with 16 multiple-choice questions (Appendix 1). Professionals answered the questionnaire individually in their workplace, and if there were any difficulties in comprehending the questions, the investigator explained the question content.

For the analysis of workers' auditory and nonauditory symptoms, the following variables were considered: earache, intolerance to intense sounds, auricular plenitude, tinnitus, dizziness, headache, irritability, talking difficulties in a noisy environment, inattention, and sleep alteration.

The Statistical Package for the Social Sciences (SPSS) software, version 16.0, was used for data input and processing, and quantitative analysis. With descriptive analysis purposes, a frequency distribution was performed of the categorical variables involved in the answers of studied professionals and analysis of central and dispersion tendency measures of continuous variables. In the statistical analysis, $\chi^{2}$ - and Fisher's exact tests were used to compare the variables between the two groups of professionals: drivers and nursing technicians.

\section{RESULTS}

The sample comprised 36 professionals. With regard to the model of ambulance, 19 (52.8\%) employees worked in a Sprinter CDI 315 ambulance, 13 (36.1\%) in a Ducato, and $4(11.1 \%)$ in a Fiorino.

Regarding the occupations, 23 (63.9\%) participants were drivers and $13(36.1 \%)$ were nursing technicians. All of them reported a 12-hour workday and $32(88.9 \%)$ declared working in two different companies. The work time in ambulances varied from 2 to 30 years.

With regard to occupational data, eight (22.2\%) employees said that they had previously worked in a noisy place and three $(8.3 \%)$ reported feeling indisposed after a workday. In addition, time of exposure to noise since the first job varied from 2 to 32 years.

Regarding hearing, $75 \%$ professionals consider their own hearing as excellent, great, or good, and $25 \%$ mentioned having a reasonable or bad hearing.

As to the performance of audiometry exam, $26(72.2 \%)$ professionals reported a normal audiometry examination, $8(22.2 \%)$ an altered one, and $2(5.6 \%)$ said they did not take the exam.

Among the most reported auditory symptoms by the professionals, tinnitus (38.9\%) and intolerance to intense sounds (27.8\%) were the most mentioned. Other auditory symptoms such as auricular plenitude $(22.3 \%)$ and earache $(2.8 \%)$ were also reported.

With regard to nonauditory symptoms, most of the professionals (47.2\%) mentioned irritability. Professionals also mentioned other symptoms such as headache (38.9\%), talking difficulties in a noisy environment (33.3\%), and sleep alteration $(33.3 \%)$.

When audiometry exam performance, perception of employees regarding hearing, and auditory symptoms with the professional occupation were associated, the results described in Table 1 were obtained.

Table 2 shows nonauditory symptoms separated according to the role of ambulance members.

\section{DISCUSSION}

This study allowed identifying auditory and nonauditory symptoms reported by professionals that work in ambulances and verifying their relation with the professional's role. These aspects have not been described in national and international studies yet; however, they are very important for comprehending the interferences in work activities of ambulance workers' lives.

The instrument used for self-perception evaluation of health aspects from ambulance workers was a questionnaire. Most studies reported in literature ${ }^{(12,13)}$ also used health selfperception questionnaires because they are a great assessment tool and a global indicator that considers, besides possible diseases of the subject, the impact that they create in physical, social, and mental welfare. Even though the instrument has not been validated, some questions used (e.g., "Do you feel you have a hearing problem?"; "In general, would you say your hearing is 'excellent', 'very good', 'good', 'regular' or 'bad'?") were asked for the Brazilian population in 
Table 1. Auditory symptoms according to the role of 36 ambulance members

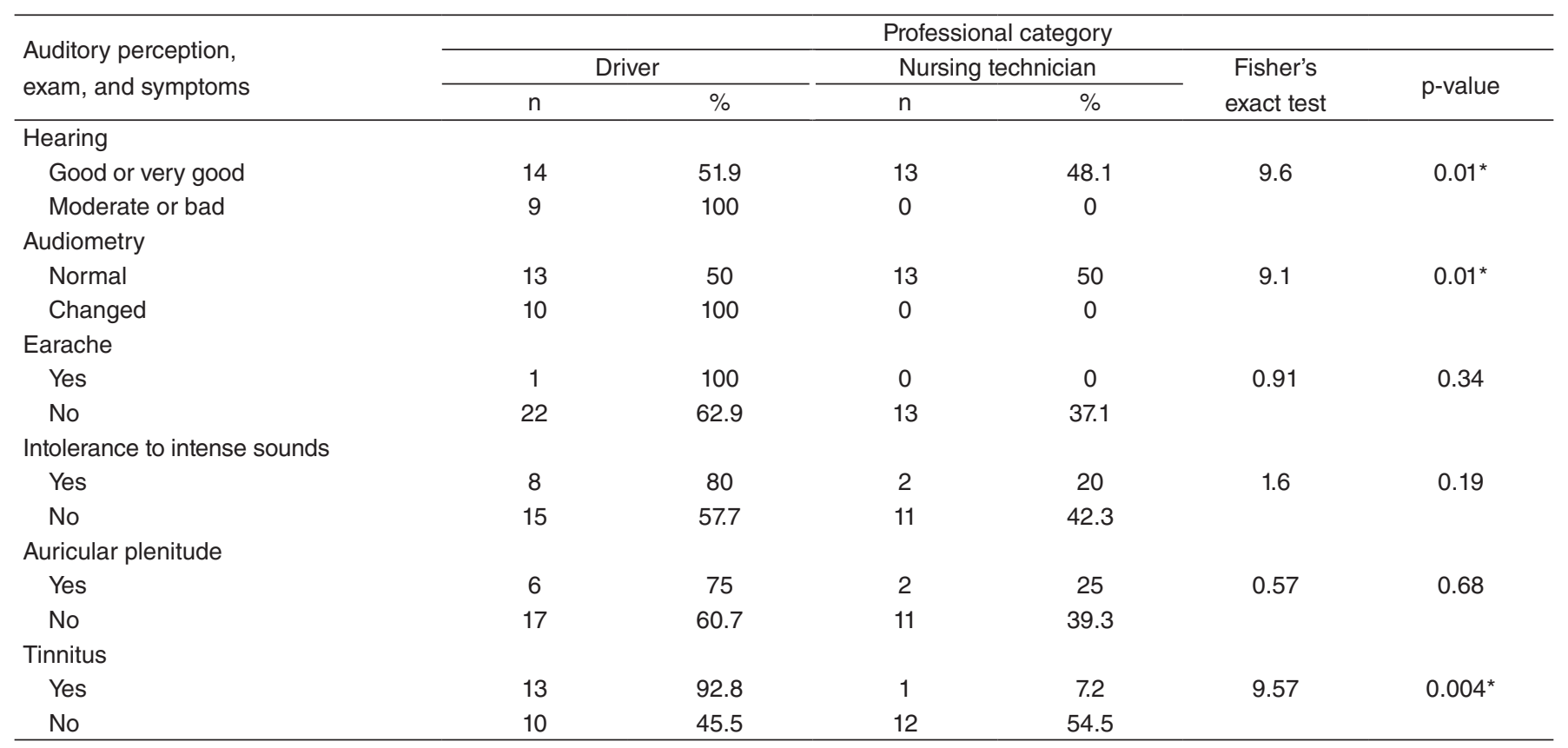

*Statistically significant values $(p \leq 0.05)$.

Table 2. Nonauditory symptoms reported by drivers and nursing technicians

\begin{tabular}{|c|c|c|c|c|c|c|}
\hline \multirow{3}{*}{ Nonauditory symptoms } & \multicolumn{6}{|c|}{ Professional category } \\
\hline & \multicolumn{2}{|c|}{ Driver } & \multicolumn{2}{|c|}{ Nursing technician } & \multirow{2}{*}{$\begin{array}{l}\text { Fisher's } \\
\text { exact test }\end{array}$} & \multirow{2}{*}{$p$-value } \\
\hline & $\mathrm{n}$ & $\%$ & $\mathrm{n}$ & $\%$ & & \\
\hline \multicolumn{7}{|l|}{ Dizziness } \\
\hline No & 22 & 62.9 & 13 & 37.1 & & \\
\hline \multicolumn{7}{|l|}{ Headache } \\
\hline \multicolumn{7}{|l|}{ Irritability } \\
\hline Yes & 14 & 82.4 & 3 & 17.6 & 4.9 & $0.04^{*}$ \\
\hline No & 9 & 47.4 & 10 & 52.6 & & \\
\hline \multicolumn{7}{|l|}{ Talking difficulties in } \\
\hline \multicolumn{7}{|l|}{ a noisy environment } \\
\hline No & 22 & 62.9 & 13 & 37.1 & & \\
\hline \multicolumn{7}{|l|}{ Sleep alteration } \\
\hline Yes & 13 & 54.2 & 11 & 45.8 & 3.1 & 0.07 \\
\hline No & 10 & 83.3 & 2 & 16.7 & & \\
\hline
\end{tabular}

*Statistically significant values $(p \leq 0.05)$.

the evaluation of self-referred hearing $\operatorname{loss}^{(14)}$. Questions were accurate enough to recommend the use of self-referred hearing loss in epidemiological studies with adults when the pure tone audiometry was not feasible ${ }^{(14)}$.

Although most professionals $(75 \%)$ reported a good hearing, a great part mentioned some hearing symptoms such as tinnitus $(38.9 \%)$, intolerance to intense sounds $(27.8 \%)$, and auricular plenitude $(22.3 \%)$. These data are in agreement with several studies described in literature ${ }^{(11-15)}$.

Tinnitus is defined as a sound perception in the head without an external acoustic source with a side effect on the daily quality of life. This auditory symptom has been classified in many ways and several studies have investigated the origin of the tinnitus. It is still uncertain if hearing loss is only 
a trigger to tinnitus appearance or if it is strictly related to the intensity and quality of tinnitus because it may also be present in patients with normal audiometry. A study seen in literature showed that subjects with tinnitus and normal audiometry have auditory-evoked potentials with a significant decrease in the potential I wave amplitude (created by fibers of the primary auditory nerve), but normal $\mathrm{V}$ wave amplitude. This provides a direct physiological evidence of "hidden auditory loss" that is manifested as a decrease in the cochlear neural production and consequent renormalization of neuronal response magnitude inside the encephalic trunk. By using the created computational model, the authors showed how tinnitus could arise from a homeostatic response of neurons in the central auditory nervous system to a decreased entrance of the auditory nerve in the absence of raised auditory thresholds ${ }^{(16)}$.

A study performed to verify the prevalence of auditory and vestibular symptoms in workers exposed to occupational noise observed that auditory dysfunctions and tinnitus are frequent complains in this population ${ }^{(17)}$. Another study carried out in Campinas, São Paulo, with workers from transportation, metallurgic, textile, civil construction, and mining areas complaining about work-related health damage, found as the most reported complains: deafness (74\%), tinnitus (80.8\%), and vertigo (13.2\%).

Besides hearing-related symptoms, many professionals $(47.2 \%)$ reported irritability, headaches $(38.9 \%)$, talking difficulties in noisy environments (33.3\%), and sleep alteration $(33.3 \%)$. Therefore, continuous exposure to noise also results in the appearance of extra-auditory symptoms that will affect the subject's welfare and consequently his/her quality of life.

More exposure to noise creates chemical/metabolic processes that will result in necrosis or cellular apoptosis. These metabolic processes have the influence of noise kind (intermittent or continuous), as well as time of exposure ${ }^{(18)}$. Some studies showed that noise influences the sympathetic nervous and endocrine systems, resulting in nonspecific physiological responses such as increase of heart rate, increase of blood pressure, and vasoconstriction ${ }^{(4)}$. In addition, stress and sleep disorders are frequently reported.

These data are in agreement with a study carried out with 40 professionals exposed to occupational noise, which found anxiety $(30.30 \%)$, followed by headache, gastric disorders, and insomnia $(18.18 \%)^{(19)}$ as the most reported nonauditory symptoms. Other studies in the investigated literature also mention the appearance of nonauditory symptoms such as cardiovascular disorders, musculoskeletal alterations due to vibration exposure $^{(20)}$, digestive, behavioral, neurological and vestibular disorders, and sleep alterations.

When auditory symptoms are associated with the role performed by professionals, tinnitus was found to be more frequent among ambulance drivers when compared to nursing technicians, with a significant difference. With regard to hearing perception and audiometry exam, differences were also found in the comparison between drivers and nursing technicians. This difference can be due to the role performed by drivers because they are not only exposed to the intense noise from traffic and siren, but they also need to drive the vehicle efficiently and safely, which requires a fast reflex and a lot of attention, consequently increasing stress levels ${ }^{(21)}$.

A study carried out in Florianópolis, Santa Catarina, in a mobile intensive care unit, showed that the level of sound pressure in the rear booth varied from 89 to $90 \mathrm{~dB}(\mathrm{~A})$ when it was moving and without the use of sound signal (siren). In the front booth, in the same situation of movement and without the use of a siren, the sound intensity presented a variation of 79 to $82 \mathrm{~dB}(\mathrm{~A})$. However, when sound measurement was performed with the ambulance moving and using sound signal (siren), the sound intensity varied from 116 to $118 \mathrm{~dB}(\mathrm{~A})^{(22)}$.

A difference was also observed regarding nonauditory symptoms because irritability and talking difficulties in noisy places were more reported among drivers when compared to nursing technicians.

The findings of this study showed that workers exposed to traffic and siren noise presented tinnitus, intolerance to intense sounds, irritability, and communication alteration. These symptoms were more frequent in drivers, possibly due to higher exposure to noise and more stress during workday. The mental requirement of a paramedic driver, together with economic, administrative, physical and social factors might increase body stress load, which is the creating dysfunction of several organic disorders, including auditory symptoms such as tinnitus and nonauditory ones such as irritability ${ }^{(21)}$.

On the basis of the literature, noise can disturb work, rest, sleep, and communication in human beings. Therefore, when a person is submitted to intense noise levels, the entire body reacts to this stimulus, given by neurovegetative reactions, which may become permanent and create organic and psychological alterations ${ }^{(16)}$.

Besides the known consequences of hearing loss in high bilateral frequency and persistent tinnitus probability, there is increasing evidence that workers exposed to noise in the workplace (daily dose equal to or higher than $80 \mathrm{~dB}(\mathrm{~A})$ ) also have higher risks of accident. It seems somehow that noise exposure and auditory loss may interact to interfere with the safe performance of occupational activities ${ }^{(23)}$. Stress-related disorders are also worth mentioning as an increase of accident risk. When noise in the workplace causes temporary or permanent hearing loss, it is reasonable to expect that it may also affect psychoacoustic performance because it compromises the perception and location of environmental sounds, including speech recognition and alert signals. Hearing loss might also contribute to the risk of traffic accidents in many ways. This was confirmed in a study that observed adult pedestrians and cyclers with moderate hearing loss in higher risk of being hurt by a vehicle ${ }^{(24)}$. The same is applied to the risk of accidents by mature drivers who have a moderate hearing impairment ${ }^{(25)}$.

A large study was conducted to verify the existence of an association between occupational exposure to noise, HLIN, and driving safety. Investigations showed that daily 
occupational exposures to noise equal or higher than $100 \mathrm{~dB}(\mathrm{~A})$ and hearing losses induced by noise, even if they are very small (16 to $30 \mathrm{~dB}$ ), might interfere in the safe handling of vehicles. These bibliographic data are concerning because ambulance drivers are transporting lives at risk, and thus transportation safety is essential.

It is known that excessive noise is considered a danger in the workplace and being exposed to it is one of the 67 risk factors considered because they significantly contribute for the global burden of disease ${ }^{(26)}$. The World Health Organization ${ }^{(27)}$ has emphasized noise exposure as a danger for several decades, and there are some international standards to estimate the risk of hearing loss in the noise-exposed population.

Besides hearing loss effects, noise will directly interfere in the quality of life of a person, thus it became a public health issue. Therefore, health and education surveillance programs and periodical medical exams must be emphasized for the early diagnosis and prevention of any kind of eventual hearing loss. There is also an urgent need of taking some measures to better maintain roads, besides efforts from automobile industries to decrease the levels of noise from vehicles and to reduce the number of drivers' work hours in a day ${ }^{(11)}$.

It was not possible, in this study, to take audiometry exams in the workers. However, auditory self-perception questions have an adequate accuracy to portray hearing loss with reliability. We should also mention that the sample was decreased but it can be larger in future studies to establish a causal relation between the studied factors, a fact that was not possible with the design of the performed study - cross-sectional. Data point out important questions regarding work activity of ambulance members. Future longitudinal studies should provide more decisive evidence of the hearing profile and auditory and nonauditory symptoms of workers.

\section{CONCLUSION}

The most reported auditory symptoms were tinnitus and intolerance to intense sounds, while irritability, headache, communication difficulty, and sleep alteration were the most reported nonauditory symptoms. It was possible to observe an association between the member's symptoms and occupation. Drivers seem to have more negative impacts from occupational noise exposure than nursing technicians. Thus, it is worth emphasizing the need of a Hearing Conservation Program (PCA, acronyms in Portuguese) in urgency and emergency companies, whose workers are exposed to noises of traffic, sound alarm, and siren, to minimize or even remove harmful effects in workers' general health.

*RCO helped in the study outline, data collection, collected data interpretation, article review, and final approval of the published version; JNS helped in the study outline, data collection supervision, collected data analysis and interpretation, article review, and final approval of the published version; ATVR helped in the study outline, article review, and final approval of the published version; MCM helped in the study outline, data collection supervision, collected data interpretation, article review, and final approval of the published version.

\section{REFERENCES}

1. Fagerlonn J. Urgent alarms in trucks: effects on annoyance and subsequent driving performance. IET Intell Transp Syst. 2011;5(4):252-8.

2. Arezes PM, Bernardo CA, Mateus OA. Measurement strategies for occupational noise exposure assessment: a comparison study in different industrial environments. Int J Ind Ergon. 2012;42:172-7.

3. Cordeiro R, Clemente APG, Diniz CS, Dias A. Exposição ao ruído ocupacional como fator de risco para acidentes do trabalho. Rev Saude Publica. 2005;39(3):461-6.

4. Lusk SL, Gillespie B, Hagerty BM, Ziemba RA. Acute effects of noise blood pressure and heart rate. Arch Environ Health. 2004;59(8):392-9.

5. Majumder J, Mehta CR, Sen D. Excess risk estimates of hearing impairment of Indian professional drivers. Int J Ind Ergon. 2009;39(1):234-8.

6. Health and Safety Commission. The Noise at Work Regulations 2005 Health and Safety. Queen's Printer of Acts of Parliament. Cambridge: Handbook for the NEBOSH; 2005.

7. Brasil. Ministério do Trabalho. Portaria ${ }^{\circ} 3.214$, de 08 de junho de 1978. Descreve a Norma Regulamentadora $\mathrm{n}^{\circ} 15$ (NR-15) - Atividades e Operações Insalubres. Diário Oficial da República Federativa do Brasil, Brasília (DF); 1978 Jun 08; Suplemento [cited 2013 May 29]. Available from: http://www.mte.gov.br/legislacao/normas_regulamentadoras/nr_15.pdf

8. Equipe Atlas. Segurança e medicina do trabalho. $54^{\mathrm{a}}$ edição. São Paulo: Atlas; 2004

9. Lopes AC, Nelli MP, Lauris JRP, Amorim RB, Melo ADP. Condições de saúde auditiva no trabalho: investigação dos efeitos auditivos em trabalhadores expostos ao ruído ocupacional. Arq Int Otorrinolaringol. 2009;13(1):49-54.

10. Oliva FC, Morata TC, Lacerda ABM, Steinmentz L, Bramatti L, Vivan AG, et al. Mudança significativa do limiar auditivo em trabalhadores expostos a diferentes níveis de ruído. Rev Soc Bras Fonoaudiol. 2011;16(3):260-5.

11. Karimi A, Kazerooni F, Nasiri S, Oliaei M. Noise induced hearing loss risk assessment in truck drivers. Noise Health. 2010;12(46):49-52.

12. Rocha CH, Santos LHD, Moreira RR, Neves-Lobo IF, Samelli AG. Verificação da efetividade de uma ação educativa sobre proteção auditiva para trabalhadores expostos a ruído. J Soc Bras Fonoaudiol. 2011;23(1):38-43.

13. Martins AL, Alvarenga KF, Bevilacqua MC, Costa-Filho OA. Perda auditiva em motoristas e cobradores de ônibus. Rev Bras Otorrinolaringol. 2001;67(4):467-73.

14. Fernandes M, Morata TC. Estudo dos efeitos auditivos e extra-auditivos da exposição ocupacional a ruído e vibração. Rev Bras Otorrinolaringol. 2002;68(5):705-13.

15. Ferrite S, Santana VS, Marshall SW. Validity of self-reported hearing loss in adults: performance of three single questions. Rev Saude Publica. 2011;45(5):824-30.

16. Khan N, Khan AR, Khan A, Khan S. Frequency of hearing loss in noisy occupational settings. Journal of Medical Sciences. 2012;20(4):192-5.

17. Schaette R, McAlpine D. Tinnitus with a normal audiogram: physiological evidence for hidden hearing loss and computational model. J Neurosci. 2011;31(38):13452-7.

18. Jastreboff PJ, Hazell JW. Introduction. In: Jastreboff PJ, Hazell JW Tinnitus Retraining Therapy. Implementing the neurophysiological model. Cambridge: Cambridge University press; 2007. p. 12-3.

19. Anari M, Axelsson A, Eliasson A, Magnusson L. Hypersensitivity to sound - Questionnaire data, audiometry and classification. Scand Audiol. 1999;28:219-30.

20. Gu JW, Halpin CF, Nam EC, Levine RA, Melcher JR. Tinnitus, diminished sound-level tolerance, and elevated auditory activity in humans with clinically normal hearing sensitivity. J Neurophysiol. 2010;104:3361-70. 
21. Nunes CP, Abreu TRM, Oliveira VC, Abreu RM. Sintomas auditivos e não auditivos em trabalhadores expostos a ruído. Rev Baiana Saúde Pública. 2011;35(3):548-55.

22.Silva LF, Mendes R. Exposição combinada entre ruído e vibração e seus efeitos sobre a audição de trabalhadores. Rev Saude Publica. 2005;39(1):9-17.

23. Costa EAVG. Estudo dos constrangimentos físicos e mentais sofridos pelos motoristas de ônibus urbano da cidade do Rio de Janeiro [tese]. Rio de Janeiro: Departamento de Artes e Design, Pontifícia Universidade Católica do Rio de Janeiro; 2006.

24. Nitschke CAS, Lopes NG, Bueno RML. Riscos laborais em Unidade de Tratamento Intensivo Móvel [monografia]. Florianópolis: Universidade Federal de Santa Catarina; 2000.
25. Girard SA, Picard M, Davis AC, Simard M, Larocque R, Leroux T, et al. Multiple work-related accidents: tracing the role of hearing status and noise exposure. Occup Environ Med. 2009;66(5):319-24.

26. Lundalv J. Self-reported experiences of incidents and injury events in traffic among hearing impaired people as pedestrians and cyclists. A follow-up study of mobility and use of hearing equipment. Int $\mathrm{J}$ Rehabil Res. 2004;27(1):79-80.

27. Lim SS, Vos T, Flaxman AD, Danaei G, Shibuya K, Adair-Rohani H, et al. A comparative risk assessment of burden of disease and injury attributable to 67 risk factors and risk factor clusters in 21 regions, 19902010: a systematic analysis for the global burden of disease study 2010 . Lancet. 2012;380(9859):2224-60. 
Appendix 1. Questionário sobre sintomas auditivos e não auditivos

\section{QUESTIONÁRIO SOBRE QUEIXAS E SINTOMAS AUDITIVOS DOS TRABALHADORES}

Prezado (a) Trabalhador (a),

Com o objetivo de pesquisar as queixas e sintomas auditivos de trabalhadores expostos a ruído solicitamos a sua colaboração para o preenchimento do questionário que se segue.

\section{Informações pessoais}

Nome:

Função:

Tempo em unidades de saúde móveis:

Idade:

Sexo: ( ) Masculino ( ) Feminino

Possui algum tipo de problema auditivo?

( ) $\operatorname{Sim}$ ( ) Não

Há quanto tempo trabalha exposto a ruído?

1) Em geral você diria que sua audição é:

( ) Excelente ( ) Muito Boa ( ) Boa ( ) Razoável ( ) Ruim

\section{2) Exames audiométricos anteriores:}

( ) $\operatorname{Sim}$ ( ) Não

\section{3) Dados ocupacionais:}

3.1 - Função:

3.2 - Horas diárias de trabalho:

3.3 - Tempo de trabalho em unidades de saúde móveis:

3.4 - Exposição a ruído no trabalho

(equipamentos barulhentos)?

( ) $\operatorname{Sim}$ ( ) Não

3.5 - Sente algum mal estar após trabalhar neste ambiente ruidoso?

( ) Sim ( ) Não

Tempo total de exposição:

3.6 - Antes deste trabalho atual você trabalhou em algum

lugar muito barulhento?

( ) Sim ( ) Não

Por quanto tempo?

3.7 - Pratica alguma atividade barulhenta fora do expediente de trabalho?

( ) Sim ( ) Não

Qual? Com que frequência?

\section{4) Antecedentes pessoais:}

4.1 - Dor de Ouvido:

( ) Sim Onde? ( ) OD ( ) OE ( ) Bilateral

( ) Não

4.2 - Secreção no ouvido:

( ) Sim Onde? ( ) OD ( ) OE ( ) Bilateral

( ) Não

( ) Não sabe

4.3 - Toma algum medicamento?

$\operatorname{Sim}($ )

Não ( )

Qual?

4.4 - Você percebeu alguma mudança na sua audição depois de alguma doença séria?

$\operatorname{Sim}($ )

Não ( )

Qual doença?

4.5 - Você notou alguma diferença na sua audição depois que tomou algum remédio?
( ) $\mathrm{Sim}$
Qual? ( ) Melhorou
( ) Não
( ) Piorou

4.6 - Cirurgia de orelha:

( ) Sim Onde? ( ) OD ( ) OE ( ) Bilateral

( ) Não sabe referir o lado ( ) Não

5) Sofreu trauma craniano:

( ) Sim

( ) Não

( ) Não sabe

6) Sofreu trauma acústico:
( ) Sim
( ) Não
( ) Não sabe

7) Alguma pessoa na família tem problema auditivo:

( ) Sim Qual grau de parentesco?

( ) Não

( ) Não sabe

8) Tontura:

( ) Sim Classifique seu sintoma: ( ) baixo-0 ( ) médio-1 ( ) alto-2

( ) Não

9) Intolerância a sons intensos

( ) Sim Classifique seu sintoma: ( ) baixo-0 ( ) médio-1 ( ) alto-2

( ) Não

10) Zumbido:

( ) Sim Classifique seu sintoma: ( ) baixo-0 ( ) médio-1 ( ) alto-2 Qual orelha? ( ) OD ( ) OE ( ) Bilateral

Com que frequência?

Desde quando?

( ) Não

11) Dor de cabeça:

( ) Sim Classifique seu sintoma: ( ) baixo-0 ( ) médio-1 ( ) alto-2

( ) Não

12) Irritabilidade:

( ) Sim Classifique seu sintoma: ( ) baixo-0 ( ) médio-1 ( ) alto-2

( ) Não

13) Dificuldade de entender as palavras:

( ) Sim Classifique seu sintoma: ( ) baixo-0 ( ) médio-1 ( ) alto-2

( ) Não

14) É desatento?

( ) Sim Classifique seu sintoma: ( ) baixo-0 ( ) médio-1 ( ) alto-2 ( ) Não

15) Dificuldade de conversar em ambientes ruidosos:

( ) Sim Classifique seu sintoma: ( ) baixo-0 ( ) médio-1 ( ) alto-2

( ) Não

16) Alterações no sono

( ) Sim Classifique seu sintoma: ( ) baixo-0 ( ) médio-1 ( ) alto-2

( ) Não

Questionário adaptado do padrão de Fernandes e Morata(14); primeira questão padronizada de Ferrite et al. ${ }^{(15)}$. 